\title{
The Origin of Igneous Rocks
}

\begin{abstract}
A
DISCUSSION on the origin of igneous rocks was held in Section C (Geology) of the British Association at York on September 7. The discussion was opened by Prof. Arthur Holmes, who sketched out a general schome of petrogenesis in the light of our present knowledge concerning the geological history, structure and thermal condition of the earth's crust. In certain continental regions the sedimentary and granitic layers appear to be separated from a deeper 'besaltic' layer by one which is probably composed of both acid and basic materials. The 'basaltic' layer is itself composite, a tentativo intorpretation being that amphibolite (a potential source of oversaturated basalts) is succeoded in dopth by more basic granulite (a potential source of undersaturated basalts). Beneuth these layers peridotite probably comes into place, merging within a fow tens of kilo. metres into the glassy state regarded as character. istic of the substratum. Given sorne such setting of matcrials, igneous activity could arise, either by the ascent into the crust of heat from the feebly radio. active substratum, or by the accumulation of heat in specially thickened belts of the more strongly radioactive crustal rocks. The latter process fails, however, to account for tho flooding by platoau basalts of regions where the crust has been thinned by denudation, and also for the ascent of granitic magma during orogenesis instead of long afterwards. 'Tho hypothesis of refusion of the crustal layers by heat from the substratum, with successive production of peridotitic, basaltic and granitic magmas, therefore seems to be worthy of special consideration.
\end{abstract}

From the fact that the basaltic magmas of the Inner Pacific differentiate towards trachyte and fail to produce rhyolites and dacites, it is possible to infer that the latter could be developed in quantity only where pre-existing granitic material has been available for refusion. To test the validity of this inference, which is supported by many other lines of circum. stantial evidence, Prof. Holmes suggested a method based on the generation of $\mathrm{Ca}^{41}$ from $\mathrm{K}^{41}$ and its accumulation during geological time. If a Tertiary granophyre or other acid rock had been produced by refusion of pre-existing granite, then its $\mathrm{Ca}^{11} / \mathrm{Ca}$ ratio should be of the same order as that for, say, Lewisian granite-gnoiss. If, on the other hand, the granophyre had boen a differentiate from basaltic magms, the $\mathrm{Ca}^{41} / \mathrm{Ca}$ ratio should be of the much lower order characteristic of basalt. Determinations of $\mathrm{Ca}^{41}$ by Dr. F. Allison, who has devised an extraordinarily sensitive magneto-optic method of isotope detection, are now in prograss with the view of trying out the practicability of the proposed test.

Attention was directed to the results of much recent work supporting the view that in both kratogenic and orogenic regions many 'intermediate' rocks have been generated as a result, not of differentiation acting alone, but of differentiation superimposed upon $(a)$ the hybridisation of granitic magma by relatively basic ignoous, metamorphic and sedi. mentary rocks, or $(b)$ the acidification of basic magma by sialic materials. Turning to the consideration of ultrabasic rocks, Prof. Holmos suggested that in addition to peridotites representing accumulations of early-formed crystals from basaltic magmas there are others that have been intruded as peridotite magmas. It was maintained that the conditions favourable to the refusion of crystal accumulates from basaltic magma would also suffice to generate magra from the peridotite layer at the base of the crust. The genesis of felspar-free alkali-rocks can be plausibly explained by assuming a peridotitic parentage for these rocks. It is not denied, however, that in some of its local applications the 'limestone assimilation' hypothesis has many attractive features.

From oach of the different types of parental magmas - acid, basic and ultrabasic - a wide variety of rock-types can bo produced by additive and subtractive differentiation, by assimilation, by the mixing of, and reaction between, various products (lampro. phyres ?) and by all these processes acting concomitantly. Further possibilities of variation are introduced by differential fusion, and Prof. Holmes pointed out that magmas generated under stress are likely to be of abnormal composition (spilitic ?) as compared with those due to passive refusion.

Prof. A. Brammall examined evidence for the syntectic origin (as opposed to 'pure-blooded' descent from primary basic magma) of saturated and oversaturated magmas, with special reference to quartzmonzonites, hornblende-biotite-syenites, diorites, granodiorites and granites. He endeavoured to liberate the general genetic problem from what he aptly termed "the tyranny of the silica percentage". 13y eliminating normative quurtz from analytical data for igneous, metarnorphic and sedimentary rocks and plotting the results in triangular diagrarns, he focused attention on progressive variation in the ratios of $(a)$ salic to femic constituents, and (b) $\mathrm{Ab}$ to $\mathrm{Or}+\mathrm{Cor}$, in a theoretical difforentiation suite. From this standard trend of variation the rock-types mentioned appear to be markedly aberrant. Not only does such aberration, in itself, logically hint at contamination, but also the rocktypes displaying it are those for which a syntectic origin has been frequently asserted on first principles and convincingly demonstrated by field and geochemical evidence. Moreover, the crustal rocks actually assimilated in particular cases are of the general composition predicable from the 'overlap' of composition-fields plotted. Both the basification of acid ragma, and the converse process, may be regarded as comparatively simple cases of the kind to be expected. The analytical and graphic methods outlined inay afford some lead in the difficult problem of assessing probabilities concerning the fact of assimilation, and the composition of material which may have boen assimilated at inaccessible depths before the consolidation of coarse-grained and essentially homogeneous rocks.

Prof. Brammall urged the need for intensive geochemical work on country-rocks-directed, in particular, to the study of 'consanguinity' as a further and possibly decisive criterion. Citations included progress reports on (i) the basic sills intrusive into Cambrian Shales flanking the Malverns near Eastnor, by Mr. F. G. H. Blyth, and (ii) hornblende-gabbro intrusive into Malvernian Schists at Hollybush, by Miss A. E. Cook and Prof. A. Brammall.

Dr. G. W. Tyrrell discussed the nature, mode of occurrence, and origin of basaltic magmas. He regards the existence of two main types of basaltic magma as established: the oversaturated or tholeiitic, and the undersaturated or crinanitic. In relation to geological onvironment three groups can

No. 3289, VoL. 130] 
be distinguished: (a) flood-basalts (mainly oversaturated); (b) oceanic basalts (largely undersaturated); (c) cone-basalts, including those of rift valleys, horsts and troughs (dominantly undersaturated and notably felspathoidal). It was pointed out that the oversaturated typo of magma has appeared at infrequent intervals but in enormous volumes, and that its chemical composition, as represented by basalts and quart $z$-dolorites, has been remarkably constant in space and time. While deriving undersaturated magmas directly from the basaltic layer, Dr. Tyrrell suggested that tho oversaturated typo may have originated by selective fusion of the peridotite or 'stony-meteorite' zone underlying the basaltic layer.

Dr. A. K. Wells expanded the evidence favouring refusion of ultrabasic material, with special reference to the dunite pipes of the I3ushveld Complex. Ho endorsed the opinion that these 'carrot-shaped' intrusions are magmatic infillings, but regards them as re-fused differentiation products from the noritic magma of the Complex. Slides were shown demonstrating that both chromitite and magnetite-rock (presumed to have been (lerived from the norite) have behaved as fluids towards the associated silicate rocks. This striking reversal of the usual relations makes it not unreasonable to postulate refusion of early segregations. In connexion with the origin of the alkali rocks, Dr. Wells regrets that most British petrologists seem loth to accept the 'limestoneassimilation' hypothesis. He thinks the chain of circumstantial evidence cited by Prof. Shand is sufficiontly strong to carry conviction, and he deprecates any suggestion that ijolite cannot be derivod from basaltic or granitic magma, on the ground that it unfairly rules out the 'limestone-assimilation' hypothesis altogether.

Prof. H. H. Read examined the quality of the field-evidence connected with petrogenic theories. The rapid changes in the fashionable theories are clearly due to imperfections of field.knowledge. Arguments based upon badly exposed igneous bodies, such as tho alkaline mass of Loch Borolan and Cnoc na. Sroine in Sutherland, are obviously of little value. If potrologists endeavoured to assess the quality of their field-evidence wo should have a guide to the order of validity of their conclusions. In Prof. Read's opinion, the field-evidence for refusion and palingenesis is entirely inadequate. In the case of contamination and hybridisation, however, the presence of discontinuities, and the complex and variable nature of the products, make the field-evidence of great value; but oven here, the application of knowledge gained in these obviously mixed rocks to the interpretation of rocks about which no such field. evidence is forthcoming should be made with caution. The most important testimony in favour of assimilation as a petrogenic process is that read from field-evidence.

Mr. S. I. Tomkeieff presented an interim report of an investigation carried out in collaboration with Mr. C. E. Marshall on the Tertiary dykes of north. east Ireland, with special reference to 130 dykes of the Mourne swarm. These included olivinic types, but a majority belonged to tho oversaturated and 'intermediate' types (andesitic variolites, leidleites, innimorites, etc.). The 'intermediate' types invari. ably contain half-digested xenocrysts of felspar and quartz, while xenoliths of partially fused granitic rocks are generally abundant. The field and petro. graphic evidence was found to be in perfect agroement with the views expressed by Prof. Holmes as to the origin of the similar suite of andesitic tholeiites occurring in the north of England. Mr. Tomkeieff outlined the igneous history of the Mourne centre as a whole and showed that the details are those to bo expected on the theory of successive refusion advocated by Prof. Holmes.

Mr. W. Campbell Smith, in commenting on the views expressed by the previous speakers, pointed out that, from the nature of the case, field evidence of palingenesis was not to be expected on anything more than a very limited scale. $\mathrm{He}_{\theta}$ is disposed to counsel caution in extending the explanation offerod for the evolution of leucitic rocks to the still less tractable problems of the soda-rich rocks.

Dr. H. Jeffreys said that the origin of the crustal layers themselves had not been touched upon, though he contends that this is the fundamental problem. $\mathrm{He}$ considers that the granitic and basaltic layers probably represent the products of residual magmas left over from the crystallisation of the material of the Lower Iayer, and suggested the possibility that the process may still be going on.

\section{International Institute for Documentation}

\section{$\mathrm{T}$}

HF eleventh Conference of the International Institute for Documentation was held in the Bibliothek für Kunst und Technik, Frankfurt am Main, during the week which ended on September 3. Great credit is due to Dr. Walter Schürmeyer, Director of the Bibliothek, for the excellent manner in which the Conference was planned and carried out. It is of interest to note that this Conference was the first held under the Institute's new title of "Documentation", which at the Tenth Conference (of the "Institut International de Bibliographie", as it was then called), held at the Hague on August 24-29, 1931, was chosen as a more appropriate title, in view of modern developments in the collection and classification of the records of intellectual activities.

On the first day, members of the Conference were received by the mayor and municipal authorities of Frankfurt, and by the Rector of the University, in the historical Kaisersaal des Römers; after which, a public assembly was held in the town hall, when Dr. J. A. Prins, director of the Dutch Patent Office, deliverod his presidential address. All papers presented at the Conference were issued in two bound volumes $^{1}$ to participants in advance. M. Paul Otlet, one of the founders of the Institute in Brussels, spoke on the history and fundamental principles of documentation, and Dr. Fhronfried Pfeiffer ${ }^{2}$ des. cribed the technical documentation service of the Verein deutscher Ingenieure in Berlin.

There was a short discussion of the joint paper, "Systematic Subject Indexes to Periodical Volumes" by Prof. A. F. C. Pollard and Ir. S. C. Bradford ${ }^{3}$, in which is described the method of the subject. matter index to volume I (1931) of the Power and Fuel Bulletin, a notable development of indexing practice.

In Great Britain, where an undecimalised and therefore troublesome system of measures and money is still patiently endured, one would least expect to find the decimal system extensively adopted in the classification of literature; but Dr. S. C. Brad. ford ${ }^{5}$ quotes a list of 28 important British scientific

$$
\text { No. } 3289 \text {, Vol. 130] }
$$

